\title{
The Signaling Effect of Dividends on The Market \& Financial Performance of Listed Companies in Sri Lanka
}

Karunarathne M. B. D. N., Sewwandi A. K. Y., Subhashini I. B. N., Wickrama Arachchige T. O.

To Link this Article: http://dx.doi.org/10.6007/IJARBSS/v11-i1/8471

DOI:10.6007/IJARBSS/v11-i1/8471

Received: 20 November 2020, Revised: 16 December 2020, Accepted: 28 December 2021

Published Online: 17 January 2021

In-Text Citation: (Karunarathne. et al., 2021)

To Cite this Article: Karunarathne, M. B. D. N., Sewwandi, A. K. Y., Subhashini, I. B. N., \& Arachchige, W. T. O. (2021). The Signaling Effect of Dividends on The Market \& Financial Performance of Listed Companies in Sri Lanka. International Journal of Academic Research in Business and Social Sciences, 11(1), 233-249.

\section{Copyright: (c) 2021 The Author(s)}

Published by Human Resource Management Academic Research Society (www.hrmars.com)

This article is published under the Creative Commons Attribution (CC BY 4.0) license. Anyone may reproduce, distribute, translate and create derivative works of this article (for both commercial and non-commercial purposes), subject to full attribution to the original publication and authors. The full terms of this license may be seen at: http://creativecommons.org/licences/by/4.0/legalcode

Vol. 11, No. 1, 2021, Pg. 233 - 249

Full Terms \& Conditions of access and use can be found at http://hrmars.com/index.php/pages/detail/publication-ethics 


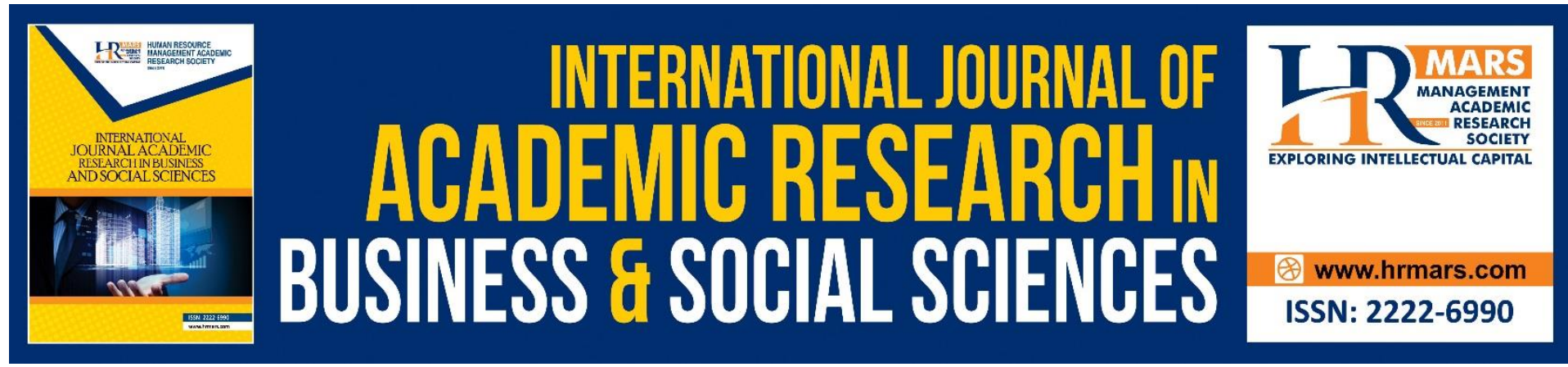

\title{
The Signaling Effect of Dividends on The Market \& Financial Performance of Listed Companies in Sri Lanka
}

\author{
Karunarathne M. B. D. N., Sewwandi A. K. Y., Subhashini I. B. \\ N., Wickrama Arachchige T. O. \\ Undergraduate SLIIT, Business School, Malabe, Sri Lanka \\ Email:mbdeshani97@gmail.com,yoshinisewwandi@gmail.com,nilupuli.dvn@gmail.com, \\ thatsarani66@gmail.com
}

\begin{abstract}
This study aims to examine the Signaling effect of dividends on the financials and market performance of listed companies in Sri Lanka. This study facilitates information regarding current and future performances, such as dividend practices, future growth projections and insights into market behaviour for stakeholders. The total population was identified as the companies listed in the CSE, which was approximately 316 firms. The sample of the study was 102 companies listed between the years 2015 to 2019. Systematic sampling was used to select the sample. In analysis, panel regression was used as the data analysis technique. STATA version 16 Statistical Software Package was used in conducting the data analysis. Random effect regression model was recommended by the hausman test._The results concluded that dividend decisions were impacted insignificantly on subsequent market performance. Dividend per share was positively and significantly impacted on both return on assets and return on equity. Dividend pay-out ratio was positively and insignificantly impacted on return on equity and also negatively and insignificantly impacted by return on assets. The current study recommends that further research could be done by focusing on dividend announcement dates and calculating the subsequent market performance, three to five months following the dividend announcement date.
\end{abstract}

Keywords: Dividend Decisions, Dividend Payout, Financial Performance, Market Performance, Signaling Effect

\section{Introduction}

Corporate finance consists of three main areas, namely dividend decisions, investment decisions and financing decisions. Through of them, dividend decisions have proved to be the most complex and puzzling area in corporate finance. Dividend decisions involve deciding how much of the earnings of the companies should be distributed among their shareholders while retaining the balance partial amount of earnings with them for future growth of the companies. Therefore, dividend decisions from an integral part of overall decision making for companies as they generate the resources and furnish information regarding company's 
prospect of development. In addition to that, dividend decisions act as a communicator to transmit significant information about company's potential expectations to stakeholders. This dividend decision changes over time between developed and underdeveloped economies. In current study, Dividend Per Share (DPS) and Dividend Payout (DPR) ratios are considered as the determinants of dividend decisions. Through DPS, investors could take proper aware of firm's both past and current financial stability. The DPR indicates what quantity will be returned to shareholders from the earnings and what amount will be retained to pay off debts or reinvest in major business operations. The greater DPR will be highly valuable to shareholders because of the higher level of return on shares which were held.

According to the signaling effect, dividends provide signals for stakeholder decision makings. For instances, if a company declares an increment in dividends, consequently the investors might earn high returns. Therefore, potential investors will pay much more attention to invest in best options to derive better earnings in future and government can have a clear idea of the company performances. Miller \& Rock (1985) hinted that the unforeseen changes in dividends, the information related to current and future cash can be identified through signaling effect.

In present study, financial performance is measured through Return on Equity (ROE) and Return on Assets (ROA). Through ROE, it represents how efficiently a company can utilize shareholder's money. ROE could also be contemplated as return on net assets, since the ratio shows the amount of profits that the entity generates in relation to its shareholder's equity. ROE is equivalent to the subtraction between total assets of a company and its debt. Whereas, ROA is a profitability ratio that shows the amount of profits that an entity could earn in relation to its total assets. In other words, ROA provides the efficiency in which the company is generating profits using the assets or the economic resources available to the company. Regarding to the market performance, it may fluctuate due to different variations. Those variations will directly impact on every industry in the country. Inconsistency of the market price of shares will conclude that how much pressure has put by dividend decisions on company's performances. Market based rate of return and Sharpe Ratio were used to measure market performance for this study. The market-based rate of return pinpoints the investors whether it is worth to invest in the company or exit.

Furthermore, Sharpe Ratio is one of the best key indicators to measure the market performance which assist stakeholders to take awareness of investment return related to its risk. The reason of conducting this study is to explore the impact of dividend decisions and signalling effect of dividends on financial and marketing performance of all sectors of listed companies in Sri Lanka.

\section{Originality Value}

There was hardly any research that have utilized the Sharpe ratio to determine the market performance relating to determining the signaling effect of dividends. Therefore, the novelty of this research was using the Sharpe ratio.

\section{Research Objective}

Main Objective

- $\quad$ To investigate the signaling effect of dividend decisions on financial performance and market performance of listed companies in Sri Lanka. 


\section{Sub objectives}

- To determine the impact of dividend decisions on subsequent market performance

- To determine the impact of dividend decisions on current financial performance

- To explore the alternative methods of assessing the impact of dividend signaling on firm's subsequent market performance

\section{Problem Statement}

Sri Lankan firms faced many complications when making dividend decisions over the last five years (CSE, 2019). There were considerable fluctuations on the behavior of dividend payout from 2015 to 2019 due to various situations such like Easter Sunday attack, political uncertainty, impacts of foreign intervention, fluctuations of foreign exchange rates, economic collapse. The current study is expected to determine how the fluctuations of dividend have been impacted on both subsequent market performance and financial performance. Figure 1.1 clearly illustrates the problem statement.

\section{Figure No.1: Problem Statement}

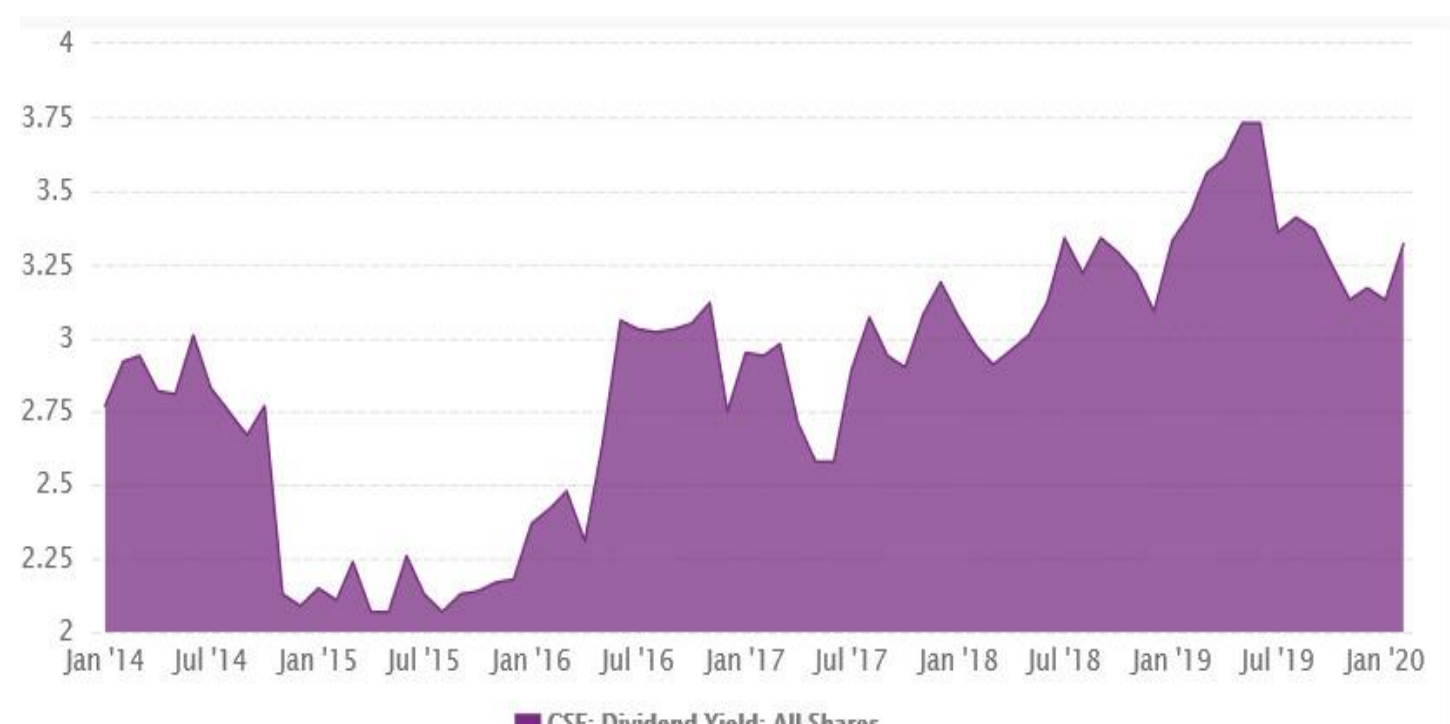

\section{Literature Review}

Prosperous companies are earning profits and these profits may be invested in firms' regular operations, securities such as bonds, stocks, certificates on deposits, commercial papers, pay off debts and finally distribute dividends for shareholders (Tamrin, Mus, Sudirman, \& Arfah, 2017). Usually, dividends are determined by the board of commissioners by evaluating the financial position of last periods during a meeting. According to the available data of developing and emerging markets, it has been proven that the earnings of companies who pay dividends have better quality than the earnings quality in non-dividend paying companies (Nguyen \& Bui, 2019). This research will be mainly focused on earnings quality. Earnings quality can be categorized into two major parts such as accounting based earnings quality and market-based earnings quality. Nguyen \& Bui (2019, p.305) hinted that "Earnings quality usually includes accruals quality, persistence, predictability, conservatism, timeliness, smoothness, etc." Among the above dimensions, accruals quality, persistence, predictability and smoothness are useful to measure accounting-based earnings quality. Value relevance, 
timeliness and conservatism are the dimensions which are helpful to measure market-based equity quality (Nguyen \& Bui, 2019).

\section{Signaling Theory}

Signaling theory states that the dividend policy acts as a communicator and is able transmit significant information to the investors about the company's future expectations. Announcements of cash dividends help the shareholders to convey significant information about the company's future profitability to the investors. There were circumstances that signaling theory breached. One of the circumstances was proved by (Wijekoon \& Senavirathne (2019) research, firm's dividend policy issues complicated signals to the investors. Managers are not always leading dividend policy as value-maximizing for shareholders.

\section{Agency Theory}

Agency theory arises when the interest of shareholders and interest of managers do not coordinate. Managers are not always leading dividend policy as value-maximizing for shareholders and they mostly think to conduct dividend policy as maximizing their own private benefits such as salary and bonuses. However, it should be noted that the argument exists when some managers are making dividend decisions in respect of their interests, instead of focusing on shareholders' wealth maximization (DeAngelo \& DeAngelo, 2006)

\section{Bird in Hand Theory}

This theory described that dividends are less risky than capital gains as dividends are certain. Therefore, investors prefer dividends rather than capital gains (Amidu, 2007). This theory proves one of the most popular proverbs that are "a bird in the hand is worth two in the bush,". Due to this, each firm has a duty to maintain better dividend policy to maximize the company's stock price (Al-Malkawi, Determinants of Corporate Dividend Policy in Jordan: An Application of the Tobit Model, 2007). On the other hand, the past literature Hussainey, et al. (2011) has proven a disagreement of Bird in Hand in Theory by the following statement "instead of the tax drawback relating to the dividends, better way of managing dividends of a firm issues some green signal for investors about the firm".

\section{Clientele Effect}

This is a concept when dividend policy changes, it will directly impact on the behaviours or reactions of various types of investors and eventually it may lead to volatility of market share prices. Furthermore, reactions and behaviors of investors may differ according to the changes of dividend policy, taxes and other policies. Primary assumption of this specific theory is, that the investors usually get attracted to the different company policies at first and make efforts to adjust their stock holdings when company policies have changed (Investopedia, 2018).

\section{Tax Effect}

This theory illustrates that lesser dividend payout ratios will reduce the cost of capital and enhance the market share price. Further, it describes lesser dividend payout ratios will be helpful to maximize the firm's value. This theory is completely opposite to the bird in hand theory. Since it argues against the assumption of bird in hand theory, this theory is built on different assumptions such as dividends will be taxed under the higher tax rates than the capital gains, dividends could be taxed immediately than the capital gains and investors might 
be highly focused on companies with low dividend payout (Al-Malkawi, Rafferty, \& Pillai, Dividend policy and share price volatility:UK evidence, 2011).

\section{Gordon's Theory}

According to Gordon's theory, current dividends are more essential to evaluate market value of a firm. It is one of the famous calculation models used to evaluate market value by using the dividend policy. Further, Gordon's theory explains about "the relationship between rate of return and the cost of capital relating to market price per share" (efinancemanagement.com, 2020). But this model could not be used for companies with low growth rates and non-dividend paying companies (Acheampong \& Agalega, 2013).

According to Abdi (2010), this research study extracted the following statement from Abdi (2010,p.10). "The theory stipulates that payment of dividend conveys information to the market with respect to expected future earnings of the company". Further, this study stated, increasing of dividends would be a promise towards the positive trend of future earnings and this research study stated the most prominent fact such as, if a company decided to declare more amount of dividend payment than the market.

Following Al-Shattarat, et al. (2018) and Healy \& Palepu (1988)studies discussed about the positive and significant impact of signaling effect. Al-shattarat, et al. (2018) research was focused on "Do dividend announcements signal future earnings changes for Jordanian firms". This research study mainly determined the market performance by using both Nissim \& Ziv (2001) model, Fama \& French (2000) model. Results of Al-shattarat, et al. (2018) research illustrates the positive and significant impact of signaling effects on dividends.

Healy \& Palepu (1988) research study was focused on determining the signaling effect. It mentioned that the firms which stopped dividend payments expereince in decrease of profits. It indicates that if a company pays more dividends, profits will be declined within the particular year.

Following Deeptee \& Roshan (2009),Modilgani \& Miller (1961) and Chowdhury, et al. (2014) studies discussed about the positive impacts of signaling effect.Deeptee \& Roshan (2009) stated, even though, the managers apply dividends to convey the information, dividend changes might not issue the perfect signal. In addition to that, Easterbrook (1984) mentioned that the enhancing of dividends will issue an ambiguous signal to recognize a developing firm or a poor firm.

Modigliani and Miller (1961) research study stated that there is no relationship between firm's market value and its dividend policy while having the perfect stock market. In reference to this theory, there was some research which proved that there is no or little impact of signaling effect on future earnings (Watts, 1973; Gonedes, 1978; Penman 1983).

According to Chowdhury, et al. (2014), however, in the Sri Lankan context, dividend announcement date will not be useful as the investors have an irrational behaviour. This is because Sri Lanka is not an emerging market. Basically, the signaling effect of dividends could not be practiced due to the probability of greater managerial incompetence, poor governance practices and inadequate financial forecast skills among investors. 
Masum (2014); Abdullah Al- Hasan, et al. (2013); Baskin (1989) studies discussed about the determining the impact of dividends on market performance. Masum (2014) research paper has focused on dividend policy and its impact on stock price. PAT, EPS and ROE were considered as moderating variables and only share market price was considered as a dependent variable which was useful to measure market performance of firms. Results of Masum (2014) research mentioned, ROE and Stock Price were positively and significantly correlated.

Abdullah Al- Hasan, et al. (2013) research paper has done their research under the topic of "the Effect of Dividend Policy on Share Price". Market price per share (MPS) is the dependent variable of this study. DPS, Retained Earnings Per Shares are the independent variables. There is a positive relationship between DPS and MPS.

According to Baskin (1989), DPR was chosen as the independent variable and stock price volatility was chosen as the dependent variable. From the results and findings section the particular research, it has found that there was a positive but not significant relationship between dividend policy and stock price volatility.

Following Chauhan, et al. (2019); Priya \& Nimalathasan (2013) and Amidu (2A007) studies discussed about the impact of dividends on financial performance. The Chauhan, et al. (2019) research paper defined dividend policy as "a compensation payable to shareholders for risk tolerance. DPS, EPS, DPR and Price Earnings Ratio (PER) were considered as dependent variables and ROA and ROE were considered as dependent variables. There is no significant relationship between DPR and ROA.

Priya \& Nimalathasan (2013) conducted a research on the "Dividend policy as the decision to pay out earnings against retaining and reinvesting them", which concluded that an improvement in financial well-being of a company has a positive impact on company's dividend policy.

According to Amidu (2007) research paper, dividend policy and Payout Ratio were considered as the independent variables and ROA, ROE and Tobin's $Q$ were considered as dependent variables of this study. In the results section, there was a positive and significant and negative relationship between ROA and Dividend policy.

Following Al-shattarat, et al. (2018) and Chowdhury, et al. (2014) studies discussed about the way of assessing the signaling effect. Al-shattarat, et al. (2018) research study mainly focused on event study methodology to determine the signaling effect of dividend decisions. The ulimate objective of event study management is to determine whether the shareholders earn excess returns or not when asscociating with special events. Applications of event study methodology within this research were described as follows. Firstly, the general assembly meeting date was considered as the event date. Then, Al-shattarat, et al. (2018) study was mainly focused on 100 daily trading observations. Selected event period was from day $\mathrm{T}$ to time $T(T=-11 \&$ Time $T=-110)$. Further 11 trading days were considered.

Relating to Chowdhury, et al. (2014) research study, methodology section was mainly focused on simple univariate analysis. This research study used Nissim \& Ziv (2001) model to examine 
the signaling effect of dividend decisions. To avoid the weaknesses of Nissim \& Ziv (2001) model, Fama \& French (2000) model was used.

In present study, signaling effect of dividend decisions was determined through the subsequent market performance and current financial performance. Adjusted market rate of return and Sharpe ratio were recommended to measure the signaling effect.

\section{Methodology}

This section involves in research methodology that is supportive to accomplish the research objectives. The current study attempts to determine the signaling effect of dividends on subsequent market performance and current financial performance.

Figure No.1: Conceptualization Framework Independent Variable

\section{Dependent Variable}

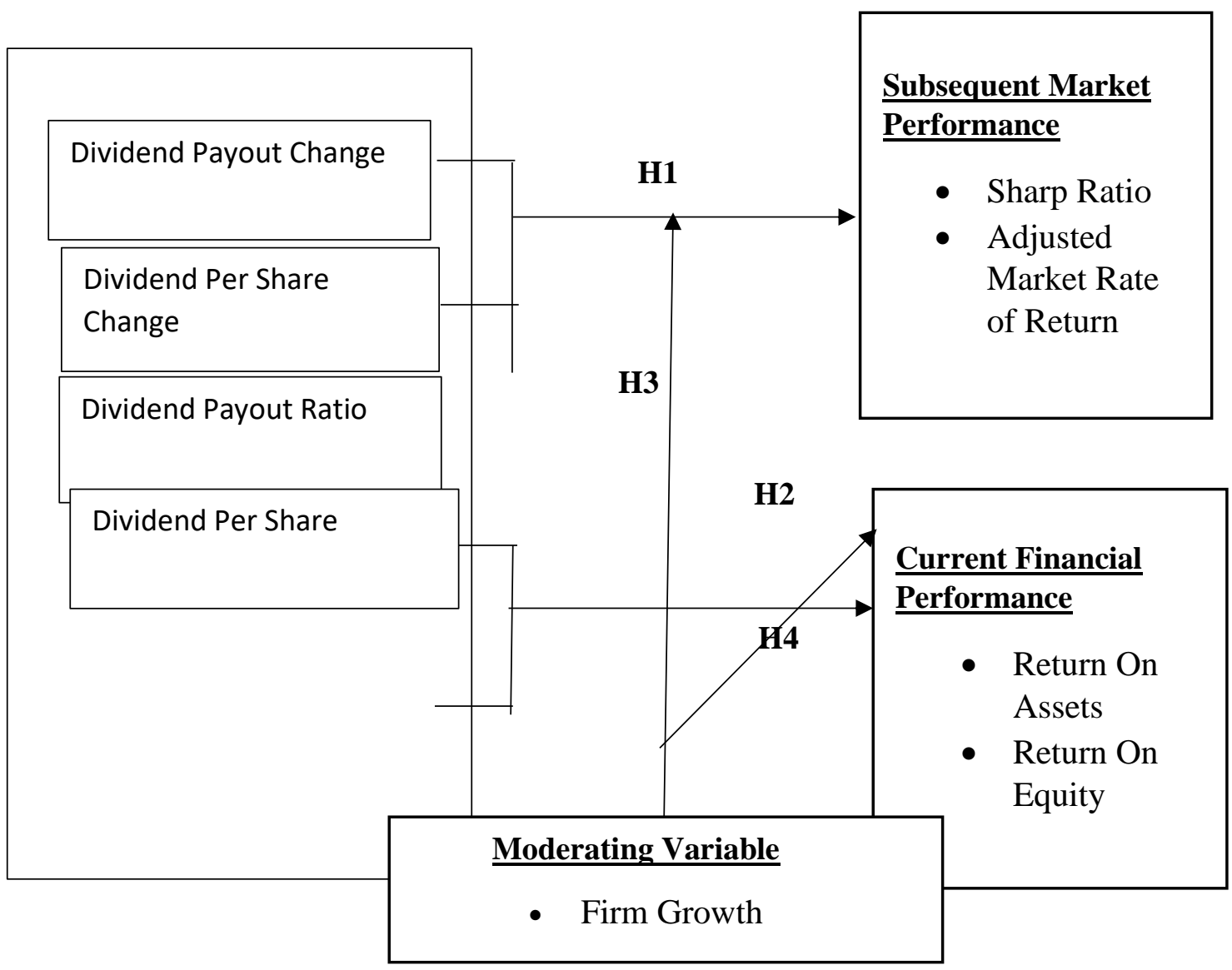

\section{Sample of the Study}

When selecting the sample, there were 316 total companies on $12^{\text {th }}$ July 2020 along with 21 sectors in the CSE website. The current study used systematic sampling technique to extract the sample for each sector category. Moreover, according to systematic sampling the current study selects every second company from the listed order (12 ${ }^{\text {th }}$ July 2020$)$ in the CSE. After conducting the systematic sampling method, the sample size was 158 companies. Out of 158 companies 56 companies had to be omitted as there was no sufficient information available and therefore the remaining 102 companies were selected as finalized sample 


\section{Sources of Data}

Both market performance and dividend per share were calculated by using the market data obtained from CSE. Relevant data regarding to Dividend Payout Ratio, Return On Assets and Return On equity were gathered from published annual reports on CSE.

\section{Analytical Tools \& Techniques}

Panel regression model with fixed effect model and Random Effect model was used to achieve the objectives of the study as the major analytical technique. Panel regression model was built by using STATA version 16 software.

\section{Diagnostic Tests}

The current study followed three diagnostic tests through STATA. Which diagnostic tests are multi-collinearity test and heteroscedasticity test.

Through the descriptive statistics, normality test was done to determine whether the data set is normally distributed or not.

Multi-collinearity test was done to explore whether there are similarities between independent and dependent variables of the study or not. Under the heteroscedasticity test, Breusche-Pegan-Godfrey test was followed to determine whether the errors or disturbances happened in linear regression models or not.

\section{Mode of Analysis}

Table 6.1 illustrates the equations for calculating the dividend decisions indicators, financial performance indicators and market performance indicators.

Table No.1: Operationalization of variables

\begin{tabular}{|c|c|}
\hline \multicolumn{2}{|l|}{ Dividend Decisions Indicators } \\
\hline Dividend Per Share (DPS) & $\begin{array}{l}\text { Directly extracted from the market data } \\
\text { obtained from CSE }\end{array}$ \\
\hline Dividend Payout Ratio (DPOR) & Dividend Per Share / Earnings Per Share \\
\hline Dividend Payout Change (DPOR_C) & $\begin{array}{l}\text { Subsequent year's Dividend Payout Ratio - } \\
\text { Current year's Dividend Payout Ratio }\end{array}$ \\
\hline Dividend Per Share Change (DPS_C) & $\begin{array}{l}\text { Subsequent year's Dividend Per Share- Current } \\
\text { year's Dividend Per Share }\end{array}$ \\
\hline \multicolumn{2}{|l|}{ Financial Performance Indicators } \\
\hline Return On Assets (ROA) & Profit After Tax / Total Assets \\
\hline Return On Equity (ROE) & (Profit After Tax - Preferred dividends)/Equity \\
\hline \multicolumn{2}{|l|}{ Market Performance Indicators } \\
\hline $\begin{array}{l}\text { Subsequent Adjusted Market Rate of } \\
\text { Return (AMRR_S) }\end{array}$ & Stock's rate of returns - ASPI's rate of returns \\
\hline Subsequent Sharpe Ratio (SR_S) & $\begin{array}{l}\text { Mean return of stocks - Risk free } \\
\text { rate)/Standard deviation of returns }\end{array}$ \\
\hline
\end{tabular}

Multiple regression model was used to determine the signaling effect of dividends on both subsequent market performance and current financial performance. Since the current study focused on major four dependent variables, following four models were built. 


$$
\begin{aligned}
& \mathrm{SR}_{\mathrm{t}}=\alpha+\beta 1\left(\text { DPORt }-\mathrm{DPOR}_{\mathrm{t}-1}\right)+\beta 2\left(\mathrm{DPSt}-\mathrm{DPS}_{\mathrm{t}-1}\right)+\beta_{3} \mathrm{~F}_{-} \mathrm{GROW}(1) \\
& \text { AMRR }_{\mathrm{t}}=\alpha+\beta_{1}\left(\mathrm{DPOR}_{\mathrm{t}}-\mathrm{DPOR}_{\mathrm{t}-1}\right)+\beta 2\left(\mathrm{DPSt}-\mathrm{DPS}_{\mathrm{t}-1}\right)+\beta_{2} \mathrm{~F}-\mathrm{GROW}(2) \\
& \text { ROA }=\alpha+\beta_{1} \text { DPOR }_{t}+\beta_{2} \text { DPS }_{\mathrm{t}}+\beta_{3} F_{-} \text {GROWTH }{ }_{\mathrm{t}}+\varepsilon \text { (3) } \\
& \text { ROE }=\alpha+\beta_{1} \text { DPOR }_{\mathrm{t}}+\beta_{2} \mathrm{DPS}_{\mathrm{t}}+\beta_{3} \mathrm{~F}_{-} \mathrm{GROWTH}_{\mathrm{t}}+\varepsilon \text { (4) }
\end{aligned}
$$

\section{Findings}

\section{Multi-collinearity Test}

Table No. 1: Multi-collinearity Test Results

\begin{tabular}{lll}
\hline Variable & VIF & Tolerance (1/ VIF) \\
\hline DPS & 1.02 & 0.981300 \\
\hline DPOR & 1.00 & 0.996351 \\
\hline DPS_C & 1.01 & 0.988268 \\
\hline DPOR_C & 1.01 & 0.991134
\end{tabular}

Multi-collinearity Test checked whether there is a similarity between independent variables and similarities between independent variables will result for very strong correlation. The test can estimate by evaluating VIF and Tolerance. If VIF value remains between1-10, it will consider as there is no multi-collinearity.

\section{Heteroscedasticity Test}

Table No.2: Heteroscedasticity Test Results

SR_S

\begin{tabular}{llc} 
& \multicolumn{1}{c}{ SR_S } \\
\hline Prob $>$ Chi 2 & 8.89 & \\
\hline & 0.0029 & \\
\hline & & AMRR_S \\
\hline Chi 2 & & \\
\hline Prob > Chi 2 & 0.000 & \\
\hline & & ROA \\
\hline & & \\
\hline Chi 2 & 3.21 & \\
\hline Prob > Chi 2 & 0.073 & \\
\hline & & ROE \\
\hline Chi 2 & & \\
\hline Prob > Chi 2 & 0.09 & \\
\hline
\end{tabular}

In table 3, According to the values in the table it's seen that, the $p$ value of both SR_S and AMRR_S is lower than 0.05. Having a $p$-value $<0.05$ indicates that the value is significant. It implies that there are constant variances in both SR_S and AMRR_S. Hence, both variables have a heteroscedasticity and not a homoscedasticity. Therefore, the Random Effect Regression models of both AMRR_S and SR_S were adjusted using robust regression. According to table 3 , having a p-value $>0.05$ indicates that the value is insignificant. It implies that there are no constant variances for both ROA \& ROE. Hence, both ROA and ROE have not a heteroscedasticity. Therefore, the Random Effect Regression results of ROA were not adjusted using robust. 
Hausman Test

\begin{tabular}{cr} 
Table No.3 - Hausman Test Results \\
\hline Chi2 & 0.03
\end{tabular}

Prob > Chi2 $\quad 0.9985$

Hausman test was performed to select the best fitted panel regression model among the Fixed Effect model and Random Effect model. Table 4 clearly illustrates the results of Hausman test. Since the $p$ value is greater than 0.05 , Random Effect model was chosen as the best fitted model.

\section{Panel Regression Model}

Table No. 4: Random Effect Regression Model

\begin{tabular}{|c|c|c|c|c|c|}
\hline AMRR_S & Coefficient & $\begin{array}{l}\text { Robust } \\
\text { Error }\end{array}$ & Std. & Z & $P>Z$ \\
\hline DPOR_C & -0.003 & 0.019 & & -0.17 & 0.867 \\
\hline DPS_C & 0 & 0.008 & & 0 & 0.996 \\
\hline F_GROW & 0.034 & 0.032 & & 1.06 & 0.289 \\
\hline Const. & -0.565 & 0.688 & & -0.82 & 0.412 \\
\hline R squared & & $0.22 \%$ & & & \\
\hline Prob > chi2 & & 0.1554 & & & \\
\hline SR_S & Coefficient & $\begin{array}{l}\text { Robust } \\
\text { Error }\end{array}$ & Std. & Z & $P>Z$ \\
\hline DPOR_C & -0.011 & 0.015 & & -0.74 & 0.458 \\
\hline DPS_C & 0.012 & 0.008 & & 1.52 & 0.128 \\
\hline F_GROW & 0.012 & 0.063 & & 0.19 & 0.847 \\
\hline Const. & -1.361 & 1.346 & & -1.01 & 0.312 \\
\hline R squared & & $0.13 \%$ & & & \\
\hline Prob > chi2 & & 0.3232 & & & \\
\hline ROA & Coefficient & Std. Error & & Z & $P>Z$ \\
\hline DPOR & 0 & 0.002 & & -0.43 & 0.667 \\
\hline DPS & 0.002 & 0 & & 5.68 & 0 \\
\hline F_GROW & 0 & 0.002 & & 0.17 & 0.867 \\
\hline Const. & 0.037 & 0.039 & & 0.93 & 0.35 \\
\hline R squared & & $6.51 \%$ & & & \\
\hline Prob > chi2 & & 0.000 & & & \\
\hline ROE & Coefficient & Std. Error & & $\mathbf{Z}$ & $P>Z$ \\
\hline DPOR & 0 & 0.004 & & 0.05 & 0.962 \\
\hline DPS & 0.006 & 0.001 & & 6.49 & 0 \\
\hline F_GROW & 0.011 & 0.004 & & 2.64 & 0.008 \\
\hline Const. & -0.184 & 0.09 & & -2.04 & 0.041 \\
\hline
\end{tabular}




\begin{tabular}{ll}
\hline R squared & $9.70 \%$ \\
\hline Prob $>$ chi2 & 0.000 \\
\hline
\end{tabular}

$\mathrm{SR}_{\mathrm{t}}$

$$
=\alpha+\beta 1\left(\text { DPORt }- \text { DPOR }_{t-1}\right)+\beta 2\left(\text { DPSt }- \text { DPS }_{\mathrm{t}-1}\right)+\beta_{3} F_{-} \text {GROW }
$$

There is a statistically insignificant impact of the DPOR_C on SR_S which is seen, as the $p$ value of 0.458 is greater than the significant level of 0.05 and $z$ value ( $t$ test) is lower than 1.96. Furthermore, there is a statistically insignificant impact of the DPS_C on SR_S as the $p$ value of 0.128 is greater than the significant level of 0.05 and $z$ value ( $t$ test) is lower than 1.96. Statistically insignificant impacts indicate that the changes of the dividend decisions won't convey adequate signals about the subsequent market performance of a firm.

Furthermore, Table 5 illustrates the negative relationship between DPOR_C and SR_S due to the negative value of the coefficient statistics relating to DPOR_C. The negative relationship indicates that the increasing of DPOR_C minimizes the value of SR_S. In addition to that, the positive coefficient statistics of DPS_C indicates a positive relationship between DPS_C and SR_S, which implies that an increase of DPS_C would maximize the SR_S.

$$
\mathrm{AMRR}_{\mathrm{t}}=\alpha+\beta_{1}\left(\mathrm{DPOR}_{\mathrm{t}}-\mathrm{DPOR}_{\mathrm{t}-1}\right)+\beta_{2}\left(\mathrm{DPS}_{\mathrm{t}}-\mathrm{DPS}_{\mathrm{t}-1}\right)+\beta_{3} \mathrm{FSIZE}_{-}+\varepsilon
$$

The results illustrate the statistically insignificant impact of DPOR_C on AMRR_S which is seen from the generated $p$ value of 0.867 , that is greater than 0.05 and the $z$ value ( $t$ test) that is lower than 1.96. Furthermore, Table 5 shows that there is a statistically insignificant impact from the DPS_C on AMRR_S since the $p$ value of 0.996 is greater than 0.05 and $z$ value (t test) is lower than 1.96. Statically insignificant impacts indicate that DPOR_C won't convey the adequate level of signals about the market performance of a firm.

In addition, table 5 represents that both DPOR_C and DPS_C have negative relationships with AMRR_S, due to the negative value of the coefficient statistics relating to both of DPOR_C and DPS_C. The negative relationship indicates that the increasing of the changes in dividend decisions would reduce the AMRR_S.

The overall results relating to Objective 1 show that the current study reports the statistically insignificant impact of both DPS_C and DPOR_C on subsequent market performance.

$$
\mathrm{ROA}_{\mathrm{t}}=\alpha+\beta_{1} \mathrm{DPOR}_{\mathrm{t}}+\beta_{2} \mathrm{DPS}_{\mathrm{t}}+\beta_{3} \mathrm{~F}_{-} \text {SIZE }+\varepsilon
$$

The results indicate that there is a statistically significant impact from the DPOR_C on ROA which is seen, as the $p$ value of 0.000 is lower than the significant level of 0.05 and $z$ value $(t$ test) is greater than 1.96. Furthermore, there is a statistically insignificant impact from the DPS_C on ROA as the $p$ value of 0.667 is greater than the significant level of 0.05 and $z$ value (t test) is lower than 1.96. Statistically significant impacts indicate that the DPOR could convey significant information about the financial performance of a firm.

Furthermore, these results show a positive relationship between DPS and ROA due to the positive coefficient value. It indicates that paying a higher amount of dividends would improve the ROA ratio. However, there is a negative relationship between DPOR and ROA due to the negative value of the coefficient relating to DPOR. It indicates that paying a higher amount of dividends would decline the ROA ratio.

$$
\mathrm{ROE}_{\mathrm{t}}=\alpha+\beta_{1} \mathrm{DPOR}_{\mathrm{t}}+\beta_{2} \mathrm{DPS}_{\mathrm{t}}+\beta_{3} \mathrm{FSIZE}_{-}+\varepsilon
$$

Table 5 shows the random effect regression results among DPOR, DPS, F_GROW and ROE. The regression results illustrate a statistically significant impact of DPS on ROE, as the $p$ value of 
0.000 is lower than 0.05 and the $z$ value ( $t$ test) is greater than 1.96. A statistically significant impact implies that the DPS could provide significant information about the financial performance of a firm. In addition, the results represent the statistically insignificant impact of DPOR on ROA since the $p$ value of 0.962 is greater than the significant level of 0.05 and the $z$ value ( $t$ test) is lower than 1.96. Statistically insignificant impact indicates that DPOR wouldn't convey adequate information about financial performance.

Furthermore, the positive coefficient value of DPS and DPOR represent the positive relationships with ROE. A positive relationship indicates that paying higher amounts of dividends would improve the ROE statistics.

The overall results of objective 2 concluded by revealing mixed results. These mixed results included both significant and insignificant impacts of dividend decisions on the current financial performance.

\section{Hypotheses Testing}

Table No.5: Results of Hypothesis Testing

\begin{tabular}{|c|c|c|}
\hline Hypothesis & Result & $\begin{array}{l}\text { Accepted } \\
\text { rejected }\end{array}$ \\
\hline $\begin{array}{l}\mathrm{H}_{1} \text { - There is a significant } \\
\text { impact of changes in } \\
\text { dividend payout levels } \\
\text { and dividend per share } \\
\text { between past two } \\
\text { consecutive years on } \\
\text { subsequent market } \\
\text { performance. }\end{array}$ & $\begin{array}{l}\text { SR_S \& DPOR_C }-0.458 \\
\text { SR_S \& DPS_C }-0.128 \\
\text { AMRR_S \& DPOR_C }-0.867 \\
\text { AMRR_S \& DPS_C }-0.996 \\
\text { (All of the values are } \\
\text { insignificant) }\end{array}$ & $\begin{array}{l}\text { Null hypothesis } \\
\text { was accepted }\end{array}$ \\
\hline $\begin{array}{l}\mathrm{H}_{2} \text { - There is a significant } \\
\text { impact of dividend policy } \\
\text { ratios on current financial } \\
\text { performance }\end{array}$ & $\begin{array}{l}\text { DPS \& ROA }-0.000^{*} \\
\text { DPOR \& ROA }-0.667 \\
\text { DPS \& ROE }-0.000^{*} \\
\text { DPOR \& ROE }-0.962 \\
\text { (Two variables are insignificant } \\
\text { and other two are significant) }\end{array}$ & $\begin{array}{l}\text { Null hypothesis } \\
\text { was partially } \\
\text { accepted }\end{array}$ \\
\hline
\end{tabular}

\begin{tabular}{|c|c|c|}
\hline $\begin{array}{l}\mathrm{H}_{3} \text { - There is a significant } \\
\text { impact of a moderating } \\
\text { variable on subsequent } \\
\text { market performance }\end{array}$ & $\begin{array}{l}\text { F_GROW \& SR_S } \quad-0.847 \\
\text { F_GROW \& AMRR_S }-0.289 \\
\text { (Both variables are } \\
\text { insignificant) }\end{array}$ & $\begin{array}{l}\text { Null hypothesis } \\
\text { was accepted }\end{array}$ \\
\hline $\begin{array}{l}\mathrm{H}_{4} \text { - There is a significant } \\
\text { impact of a moderating } \\
\text { variable on current } \\
\text { financial performance. }\end{array}$ & $\begin{array}{l}\text { F_GROW \& ROA }-0.867 \\
\text { F_GROW \& ROE }-0.008^{*} \\
\text { (One value is significant) }\end{array}$ & $\begin{array}{l}\text { Null hypothesis } \\
\text { was partially } \\
\text { accepted }\end{array}$ \\
\hline
\end{tabular}




\section{Conclusion}

This study mainly focused on the signaling effect of dividends on subsequent market performance and current financial performance and revealed some important findings regarding to the signaling effect of dividends in the Sri Lankan context. According to the first hypothesis, the study disclosed that the subsequent market performance was insignificantly impacted on the dividend decisions in Sri Lankan context. Also, finding from the second hypothesis observed that there is a significant impact of DPS on the current financial performance. Third hypothesis investigated that there is an insignificant impact of firm growth on subsequent market performance. According to the fourth hypothesis, the study explored that there is an insignificant impact of firm growth on ROA and a significant impact on ROE. According to the findings, the current study recommended that dividend decisions were more significantly impacted on the current financial performance rather than the subsequent market performance. Also, among the two recommended indicators for measuring market performance, dividend decisions were more significantly impacted on Sharpe ratio rather than the adjusted market rate of return. Determining the signaling effect of dividends is one of the most challenging and unsolved issue in the corporate finance.

\section{Contribution of the Study}

Shareholders' wealth maximization is the ultimate goal of any business organization. To satisfy shareholders, companies establish a set of dividend decisions which are helpful to determine shareholders' investment decision. Through this study, companies can do changes relating to dividend decisions along with raising awareness of shareholders. This study is essential to identify the firm's current and future performances, for instance, dividend practices, future growth projections and insight of market behaviour. Furthermore, the particular research study might be helpful for stakeholders to take different decisions on various purposes such as making decisions about profit planning and investments by managers, decisions of educational and research purposes by students, making dividend payment decisions by board of directors. Apart from that, ratio analysis (ROA, ROE, DPS and DPR) of this study will be useful to gain a clear idea about determinants of dividend decisions. For example, DPS facilitates to indicate management's willingness to make consistent payout to shareholders and DPR assists to examine the company's stability and growth of future earnings.

\section{Policy Implications}

Provided that dividends had a statistically insignificant impact on the subsequent market performance, the current study recommended that a majority of the shareholders in the Sri Lankan context didn't place much concern on dividend announcements (Abdi, 2010). Further, Chowdhury, et al (2014) in his study, mentioned that since Sri Lanka is not an emerging market, testing the rational behaviour of investors on dividend announcement date would not be useful. Therefore, the dividend announcements won't adequately be reflected through the share prices. It further explains that since most investors in Sri Lanka don't immediately react based on the issued dividend announcements, dividend information won't be reflected in stock prices of a firm.

However, this study reveals that DPS had a significant and positive impact on the current financial performance. This particular impact recommends that the companies have favourable a dividend policy when they are earning more profits while having an unfavourable 
dividend policy when they are earning losses. However, according to this study, DPOR had a negative relationship with the current financial performance. This negative relationship reflects a puzzled nature and the negative correlation recommends that the most of the companies did not enhance their dividends even they were earning more profits. It seems that the most companies are maintaining constant dividend payments.

\section{Acknowledgement}

First, we would like to express our special thanks of gratitude to our supervisor Prof. Lakshman Alles for special guidance and support to complete this final thesis. We would also like to extend our gratitude to the module leader of Comprehensive Research Project Prof. Dr. Nagalingam Nagendrakumar for regularly guiding us about the content, standardized format and clearly presenting the research dissertation. We would like to express our sincere thanks to our co-supervisor Ms. Anuja Lokeshwara for regular assistance to complete this research proposal. Finally, we would like to express our heartiest gratitude to all the staff members in SLIIT Business School who were assisted to complete our final research thesis.

\section{References}

Abdi, M. A. (2010). Signaling Effect of Dividend Payment on the Earnings of the Firm : Evidence from the Nairobi Stock Exchange (Master's thesis, University of Nairobi, Nairobi, Kenya). Retrieved from http://erepository.uonbi.ac.ke/bitstream/handle/11295/14395/Abdi_Signaling\%20eff ect\%20of\%20dividend\%20payment\%20on\%20the\%20earnings\%20of\%20the\%20Firm. pdf?sequence $=3 \&$ isAllowed $=y$

Acheampong, P., \& Agalega, E. (2013). Examining the Dividend Growth Model for Stock Valuation. Research Journal of Finance and Accounting, 4(8), 112-120. Retrieved from https://www.researchgate.net/publication/318702452_Examining_the_Dividend_Gro wth_Model_for_Stock_Valuation_Evidence_from_Selected_Stock_on_the_Ghana_Sto ck_Exchange/link/597887650f7e9b27772814fo/download

Al-Malkawi, H.-A. N. (2007). Determinants Of Corporate Dividend Policy In Jordan: An Application Of The Tobit Model. Journal Of Economic \& Administrative Sciences, 23(2), 44-70. Retrieved from

https://www.researchgate.net/publication/228275551_Determinants_of_Corporate_ Dividend_Policy_in_Jordan_An_Application_of_the_Tobit_Model

Al-Malkawi, H. A. N., Rafferty, M., \& Pillai, R. (2010). Dividend Policy: A Review of Theories and Empirical Evidence. International Bulletin of Business Administration, (9), 171-200.

Retrieved from http://elibrary.vssdcollege.ac.in/web/data/books-com-sc/mcompre/Dividend\%20Policy\%20-

\%20A\%20Review\%20of\%20Theories\%20and\%20Empirical\%20Evidence.pdf

Al-Shattarat, W. K., Al-Shattrat, B. K., \& Hamed, R. (2018). Do dividends announcements signal future earnings changes for Jordanian firms. Journal of financial reporting and Accounting, 16(3), 417-442

Amidu, M. (2007). How does dividend policy affect performance of the firm on Ghana Stock Exchange. Investment Management and Financial Innovations, 4(2), 103-112. Retrieved from

https://www.researchgate.net/publication/286355892_How_does_dividend_policy_a ffect_performance_of_the_firm_on_Ghana_Stock_exchange 
Baskin, J. (1989). An emperical investigation of the pecking order hypothesis. Journal of Financial Management, 26-35. Retrieved from https://www.scirp.org/(S(czeh2tfqyw2orz553k1w0r45))/reference/ReferencesPapers. aspx?ReferencelD=1485626

Chauhan , J., Ansari, M. S., Taqi, M., \& Ajmal, M. (2019). Dividend Policy and Its Impact on Performance of Indian Information Technology Companies. International Journal of Finance and Accounting, 8(1), 36-42. Retrieved from

https://www.researchgate.net/publication/341043513_Dividend_Policy_and_Its_Imp act_on_Performance_of_Indian_Information_Technology_Companies

Chowdhury, R. H., Maung, M., \& Zhang, J. (2014). Information content of dividends : a case of an emerging financial market. Studies in Economics and Finance, 31(3), 272-290. Retrieved from https://ideas.repec.org/a/eme/sefpps/v31y2014i3p272-290.html

CSE. (2019). CSE - Colombo Stock Exchange. Retrieved March 2020, from https://www.cse.lk/home/market

DeAngelo, H., \& DeAngelo, L. (2006). Payout policy pedagogy:What matters and why (Working paper). University of Southern California. Retrieved from http://marshallinside.usc.edu/deangelo/download.htm

Deeptee, P. R., \& Roshan, B. (2009). Signaling Power of Dividend on Firms' Future profits A Literature Review. EvergreenEnergy - International interdisciplinary Journal, 1-9. Retrieved from file:///C:/Users/hp/AppData/Local/Temp/signalling-power-ofdividend-on-firms-future.pdf

Easterbrook, F. H. (1984). Two Agency - cost explanations on dividends . American Economic Review , 74, 220-230. Retrieved from https://www.semanticscholar.org/paper/TwoAgency-Cost-Explanations-of-Dividends-

Easterbrook/bd770112f04709dc5cebb24aaf3cf07616640f1b

efinancemanagement.com. (2020). Gordon's Theory on Dividend Policy. Retrieved April 2020, from https://efinancemanagement.com/dividend-decisions/gordons-theory-ondividend-policy

Gonedes, N. J. (1978). Corporate signalling, external accounting, and capital market equilibrium:Evidence on dividends, income, and extraordinary items. Journal of Accounting Research, 16(1), 26-79. Retrieved from

https://econpapers.repec.org/article/blajoares/v_3a16_3ay_3a1978_3ai_3a1_3ap_3a 26-79.htm

Healy, P. M., \& Palepu, K. G. (1988). Earnings Information Conveyed by Dividend Initiations and Omissions. Journal of Financial Economics, 2(21), 149-176. Retrieved from https://econpapers.repec.org/article/eeejfinec/v_3a21_3ay_3a1988_3ai_3a2_3ap_3a 149-175.htm

Hussainey, K., Mgbame, C. O., \& Chijoke-Mgbame, A. M. (2011). Dividend policy and share price volatility: UK evidence. The Journal of risk finance, 12(1), 57-68. Retrieved from https://www.semanticscholar.org/paper/Dividend-policy-and-share-pricevolatility\%3A-UK-Hussainey-Mgbame/6fc24c890e1d26d9c6b6ad25d88032d53110710f

Investopedia. (2018). Dividend Clientele. Retrieved April 2020, from https://www.investopedia.com/terms/d/dividend-clientele.asp

Masum, A. A. (2014). Dividend Policy and its impact on Stock Price. Global Disclosure of Economics and Business, 3(1), 9-17. Retrieved from https://www.semanticscholar.org/paper/Dividend-Policy-and-Its-Impact-on-StockPrice-\%E2\%80\%93-A-Masum/9c28730a098b5a6569fb3861ef9751a40e60ed76 
Miller, M. H., \& Rock, K. (1985). Dividend Policy under assymetric information. The journal of Finance(4), 1031-1051. Retrieved from https://onlinelibrary.wiley.com/doi/full/10.1111/j.1540-6261.1985.tb02362.x

Modilgani, F., \& Miller, M. H. (1961). Dividend policy, Growth and the valuation. Journal of Business , 34, 411-433. Retrieved from https://econpapers.repec.org/article/ucpjnlbus/v_3a34_3ay_3a1961_3ap_3a411.htm

Nguyen, T. T. N., \& Bui, P. K. (2019). Dividend policy and earnings quality in Vietnam. Journal of Asian Business and Economic Studeis, 26(2), 301-312. Retrieved from https://www.emerald.com/insight/content/doi/10.1108/JABES-07-20180047/full/html

Penman, S. H. (1983). The predictive content earnings forecasts and dividends . Journal of Finance, 36(4), 1181-1199. Retrieved from https://econpapers.repec.org/article/blajfinan/v_3a38_3ay_3a1983_3ai_3a4_3ap_3a 1181-99.htm

Priya, K., \& Nimalathasan, B. (2013). Dividend Policy Ratios and Firm Performance: a case study of Selected Hotels \& Restaurants in Sri Lanka. Global Journal of Commerce \& Management Perspective, 2(6), 16-22. Retrieved from https://www.researchgate.net/publication/259573053_Dividend_Policy_Ratios_and_ Firm_Performance_a_case_study_of_Selected_Hotels_Restaurants_in_Sri_Lanka

Tamrin, M., Mus, H. R., Sudirman, \& Arfah, A. (2017). Effect of profitability and dividend policy on corporate governance and firm value: Evidence from the Indonesian manufacturing Sectors. IOSR Journal of Business and Management, 19(10), 66-74. Retrieved from https://ideas.repec.org/p/osf/thesis/sfjqc.html

Watts, R. (1973). The information contents of dividends. The Journal of Business , 46(2), 191211. Retrieved from https://econpapers.repec.org/article/ucpjnlbus/v_3a46_3ay_3a1973_3ai_3a2_3ap_3a 191-211.htm

Wijekoon, W., \& Senavirathne, L. (2019). Impact Of Dividend Policy On Firm Performance Evidence From Listed Companies In Colombo Stock Exchange. Global Scientifc Journals, 7(10), 225-239. Retrieved from http://www.globalscientificjournal.com/researchpaper/IMPACT-OF-DIVIDEND-PolicyOn-Firm-Performance-Evidence-From-Listed-Companies-In-Colombo-StockExchange.Pdf 